This is an author produced version of a paper published in Current Opinion in Microbiology. This paper has been peer-reviewed but does not include the final publisher proof-corrections or journal pagination.

Citation for the published paper:

Svanborg, Catharina and Bergsten, Goran and Fischer, Hans and Godaly, Gabriela and Gustafsson, Mattias and Karpman, Diana and Lundstedt, Ann-Charlotte and

Ragnarsdottir, Bryndis and Svensson, Majlis and Wullt, Bjorn

"Uropathogenic Escherichia coli as a model of host-parasite interaction."

Curr Opin Microbiol. 2006 Feb;9(1):33-9.

http://dx.doi.org/10.1016/j.mib.2005.12.012.

Access to the published version may require journal subscription.

Published with permission from: Elsevier 


\title{
UROPATHOGENIC ESCHERICHIA COLI AS A MODEL OF HOST-PARASITE INTERACTION
}

\author{
C. Svanborg'1, G. Bergsten'1, H. Fischer'1, G. Godaly1, M. Gustafsson¹, D. Karpman², A- \\ C. Lundstedt'1, B. Ragnarsdottir ${ }^{1}$, M. Svensson ${ }^{1}$, B. Wullt ${ }^{3}$
}

1Department of Microbiology, Immunology and Glycobiology, Institute of Laboratory Medicine, Lund University, Lund, Sweden

2Department of Paediatrics, Lund University, Lund, Sweden

3Department of Urology, Lund University, Lund, Sweden

Corresponding author:

Catharina Svanborg, Department of Microbiology, Immunology and Glycobiology (MIG), Institute of Laboratory Medicine, Lund University, Sölvegatan 23, S-223 62 Lund, Sweden.

Tel: $+46-46-173972$

Fax: +46-46-137468

E-mail: Catharina.Svanborg@mig.lu.se 


\section{INTRODUCTION}

Urinary tract infections (UTIS) provide an excellent model to study how the host recognises and deals with mucosal pathogens [1-3]. The infecting strain encounters a microbially naïve mucosal environment where the pathogenic strains may cause acute, potentially life-threatening infections. Chronic sequels are prevalent, and there is a link between acute infection and chronicity [4,5]. The mechanisms underlying commensalism may also be studied in the urinary tract, as asymptomatic bateriuria (ABU) occurs in at least $1 \%$ of the population and the patients may carry $>10^{5} \mathrm{cfu} / \mathrm{ml}$ of Escherichia coli in the urine for months or years with no or few symptoms [6,7]. Studies in the UTI model have identified molecular mechanisms that initiate tissue attack by mucosal pathogens and that trigger the innate host response [8]. Based on these mechanisms the genetics of disease susceptibility are beginning to be understood $[9,10]$.

\section{Virulence or symbiosis}

The severity of UTI reflects the virulence of the infecting strain. In the 1940s, hemolysin was identified as a characteristic of E. coli causing extra-intestinal infections [11]. Uropathogenic E. coli (UPEC) strains were later shown to belong to a restricted set of serotypes or "clones" [12], and acute pyelonephritis and ABU strains were found to differ in surface antigen repertoire [7]. In the 1970s this information was extended to involve attachment to the urinary tract mucosa [13]. High tissue attachment was shown to characterise the most virulent strains but not the asymptomatic carrier strains. Attachment was therefore proposed as the first step in the pathogenesis of UTI, and the epithelial cell was recognised as the first sensor of tissue attack [14-16]. The molecular basis of virulence has since then been extensively studied and a number of essential virulence factors have been identified [17]. The virulence genes are encoded on pathogenicity islands, and their expression, regulation and evolution have been elegantly characterised [18-20]. Recent studies have suggested that $A B U$ strains may be attenuated pathogens, carrying deletions in the virulence genes involved in attachment and the tissue attack [21]. 
The virulence factors enable UPEC to trigger epithelial cell responses leading to inflammation, cell detachment and apoptosis, or invasion causing bacteremia [14,15,22-28]. The tissue response is lethal for the organism, however, and is unlikely that invasion offers an advantage that would drive the evolution of the virulent phenotype. The adaptation of uro-pathogenic clones occurs mainly in the large intestine, and it is more likely that virulence is "co-incidental" [29]. For example, the mucosal receptor for $\mathrm{P}$ fimbriated uro-pathogens are expressed both in the intestine and urinary tract, but ligand binding has different consequences at the two sites [30]. $\mathrm{ABU}$, on the other hand, may represent a successful adaptation, as the bacteria can persist without competition in a niche with a rich nutrient source, often for several years. In this case, the host response may be advantageous by providing signals that attenuate bacterial virulence.

\section{Responders or non-responders}

The susceptibility to UTI varies greatly in the population, as does the severity of disease in susceptible individuals [31]. Studies in pyelonephritis prone children have identified "high responders" with abnormalities that exaggerate the damaging rather than protective aspects of innate immunity $[3,32]$ and experimental infections in different mutant mice have identified a single gene defect, which causes the "high responder" phenotype [5]. Neutrophils are critical effectors of the host defence in the urinary tract and neutrophil dysfunctions, due to defective IL-8 receptor expression, cause acute pyel onephritis and renal scarring [10]. In "Iow responders," on the other hand, bacteruria establishes without evoking a response, showing that suppression of inflammatory signals may be protective even though the infection remains. Also in this case, studies in mice have identified genetic control mechanisms that decide if the host will remain asymptomatic or develop disease. Mice carrying a mutation in the signalling domain of Toll like receptor 4 (TIr4) were shown to develop an asymptomatic carrier state resembling human ABU [33-35].

This review focuses on these two steps in disease pathogenesis and their consequences for human disease. 


\section{Step 1: M echanism of pathogen recognition and host response induction}

Pathogen recognition by the mucosa is guided by molecular specificity. Attachment is an essential first step, which promotes bacterial persistence and activates the host defence signalling pathways (Figure 1; Step 1) $[13,14,36]$. The commensals mostly lack the virulence associated adhesive ligands and fail to bind to signalling receptors in the mucosa. The situation may be different in the gut, where pathogens have been proposed to actively inhibit the epithelial response by disrupting NF- $\mathrm{KB}$ dependent transcription mechanisms [37,38].

UPEC use P fimbriae for epithelial cell adherence and P fimbriae are expressed by up to $80 \%$ of the strains causing acute pyelonephritis compared to $<20 \%$ of $A B U$ strains $[39,40]$. The host cell receptors for $P$ fimbriae are glycosphingolipids, and the PapG tip adhesin binds to Gal $\alpha 1 \rightarrow 4 \mathrm{Gal} \beta$ oligosaccharide receptor epitopes, which are abundantly expressed in the human urinary tract mucosa [41-43]. The glycosphingolipid receptors also play a central role in host response induction $[27,36,44-46]$. Infection studies in animal models and human patients have shown that P fimbrial expression is essential for the uropathogenic E. coli strains to trigger the innate host response in vivo. $\mathrm{P}$ fimbriae thus fulfil the molecular Koch postulates as an independent virulence factor in the human urinary tract [36].

The mucosal response to P fimbriated E. coli is controlled by TLR4 both in vitro and in vivo $[28,47,48]$. The extra-cellular, leucinerich repeat domains of the TLRs recognize conserved microbial patterns such as LPS, but need co-receptors to function optimally [49]. TLR4 dimerisation by LPS in myeloid cells involves co-receptors CD14 and MD2 and leading to recruitment of IL-IR associated serine kinase 4 (IRAK-4) via the adaptors MyD88 and TIRAP [50,51]. As a consequence, LPS responses are severely decreased in Myd88, Irak and Tirap knock-out mice [51-53]. The uro-epithelial cells lack CD14, and respond poorly to LPS $[28,45,54]$. This inertia to LPS is probably essential to allow asymptomatic carrier state, but raises the question how TLR4 signalling may be triggered specifically by the pathogenic strains. We propose that 
fimbrial lectins and their recognition receptors selectively activate mucosal TLR4 responses [48].

In view of the CD14 independence of the epithelial response to $P$ fimbriated $E$. coli, we speculated that TLR4 signalling might involve different adaptor proteins. This hypothesis was supported by in vivo studies, in the murine UTI model [48]. The epithelial response to $\mathrm{P}$ fimbriated E. coli was controlled by the Trif/ Tram adaptors and Trif $-/$ - and Tram -/ - mice showed no significant response to infection. M yd88 -/ and the Tirap -/ - mice were fully responsive. The results suggested that fimbriae and glycoconjugate receptors offer a mechanism of "pathogen recognition" that allows TLR4 to respond selectively to pathogens at mucosal surfaces. Recognition receptors for other bacterial ligands may work in a similar manner. This mechanism offers a solution to the paradox specificity with the convergence on a limited number of mucosal TLRs.

The mechanism of human TLR4 recruitment by the glycolipid receptors is not fully understood, but our studies have identified ceramide as a possible signalling intermediate. Ceramide is the membrane anchor of the receptors, and early studies showed an increase in free ceramide after $P$ fimbrial binding. Sphingomyelinase, which releases ceramide by cleaving sphingomyelin was shown to stimulate a TLR4 dependent chemokine response and exogenous $\mathrm{C} 2$ and $\mathrm{C} 6$ ceramide triggered a TLR4 dependent cytokine response in CD14 and MD-2 negative HEK cells [55]. By confocal microscopy, the levels of membrane associated ceramide and TLR4 were shown to increase after stimulation with P fimbriated E. coli, and significant co-localization was observed in lipid rafts [47]. The results show that TLR4 signalling can be activated in the absence of CD14 and MD-2, by agonists that modify membrane glycolipids. Receptor cleavage may also be a useful defence strategy, as it would serve to release the ligand and to activate a host response.

\section{Step 2: N eutrophil defects and genetics of disease susceptibility}


The anti-bacterial defence of the urinary tract relies almost entirely on innate immunity. Following intra-vesical inoculation, bacteriuria is cleared within hours or days and neutrophils are the crucial effector cells. The infected uro-epithelial cells secrete chemotactic substances including chemokines [15,16,56]. A chemotactic gradient is created, and in response to the gradient, neutrophils leave the bloodstream, migrate through the tissues and cross the epithelial barrier into the lumen. These molecular and cellular interactions explain the emergence of leucocytes in urine, known as "pyuria", which is a classical sign of UTI. IL-8 is one of the main driving forces for neutrophils to cross the human urinary tact epithelium, and MIP-2 plays a similar role in the murine urinary tract [56-58]. It should be noticed, that several different neutrophil chemoattractants are secreted by epithelial cells and that additional studies are needed to understand their function in the response to UTI (See Figure 1; Step 2) [59,60]. IL-8 and other neutrophil activating CXC chemokines exert their effects by binding to $G$ protein coupled cell surface receptors [61-63]. Infection stimulates CXCR1 and CXCR2 expression by epithelial cells, and CXCR1 is essential for the increased neutrophil migration across infected cell layers in vitro [64].

\section{The syndrome of acute pyelonephritis and renal scarring is precipitated by a single} gene defect. We have used the murine UTI model to define the in vivo importance of chemokines and chemokine receptor and to study how neutrophil defects influence disease susceptibility $[9,35,65]$. A deletion of the murine IL-8 receptor was shown to precipitate the syndrome of acute pyelonephritis and renal scarring, by perturbing neutrophil exit across the epithelial barrier and the innate host defence. In control mice, neutrophils appeared in the kidneys within a few hours after infection, and were seen crossing the epithelial barrier into the lumen. In the process, infection was cleared with no evidence of tissue damage. The mlL-8Rh-/ - mice showed neutrophil accumulation under the epithelial barrier until abscesses were formed throughout the kidney parenchyma. In parallel, there was an increase in bacterial tissue counts and the mice developed bacteremia. In surviving mice, the kidneys shrunk in size, and 
histology revealed tissue damage with fibrosis and other signs of renal scarring $[5,10,64]$.

\section{Genetics of human disease susceptibility}

The results described above suggest at least three ways in which genetic variation may influence human disease susceptibility.

a) Recognition receptors for bacterial fimbriae. Glycolipid receptor expression varies with the $\mathrm{P}$ blood group. The results predict that an individual lacking receptors would be resistant to $\mathrm{P}$ fimbriaed $\mathrm{E}$. coli, but there are too few receptor negative individuals to investigate this hypothesis. Patients prone to UTI show a higher density of epithelial cell receptors, however, and individuals of blood-group $\mathrm{P}_{1}$ run an increased risk of developing recurrent pyelonephritis [66]. Furthermore, the receptor repertoire influences which fimbrial type can cause infection. Individuals of blood group $\mathrm{A}_{1} \mathrm{P}_{1}$ express the globoA structure on their epithelial cells and strains expressing the prs type of P fimbriae preferentially infect these individuals [67].

Glycolipid receptors expression may be modified by pharmacological inhibitors. The glucose analogue $\mathrm{N}$-butyldeoxynojirimycin (N B-DNJ) blocks the ceramide specific glycosyl transferase involved in epithelial receptor expression [68]. Receptor inhibition was shown to be protective against colonisation and inflammation in the murine UTI model, confirming that the primary receptor is one essential component in the host response [46]. This approach should be pursued also in man.

b) TLR 4 expression and signalling. The TIr4 signalling deficiency in $\mathrm{C} 3 \mathrm{H} / \mathrm{HeJ}$ or TIr4 -/ mice disrupts the inflammatory response. The unresponsiveness has two main consequences. The mice are unable to clear the infection, but develop a carrier state resembling ABU. The human TLR4 gene has been mapped to chromosome 9 (9q32q33) $[69,70]$. The extra-cellular domain combines with microbial ligands, while the cytoplasmic Toll/ IL-1 receptor (TIR)-domain controls signalling through interaction with the adaptor proteins. Based on the analogy to the $\mathrm{C} 3 \mathrm{H} / \mathrm{HeJ}$ mouse [71], we 
obtained DNA sequences from children with $\mathrm{ABU}$ and healthy controls. No sequence variation was detected in the TIR domain. Further clinical studies of TLR4 and adaptor proteins in patients with $\mathrm{ABU}$ and acute pyelonephritis are currently being performed [72].

c) Low surface expression of CXCR1 in UTI-prone children and associated genetic polymorphisms. The progression from acute disease to renal scarring in the $\mathrm{mlL}-8 \mathrm{Rh}$ KO mice suggested that a CXC chemokine receptor deficiency might underlie the susceptibility to UTI also in man. In a prospective clinical study, CXCR1 expression was found to be significantly lower in pyelonephritis prone children than in agematched controls [10]. The low CXCR1 surface expression was also reflected in lower mRNA levels [10]. DNA sequencing revealed five single nucleotide polymorphisms, SNPS, unique to the UTI-prone children. Two of the SNPS were found at a low frequency in adult controls, but three were unique to the UTI prone children [73].

\section{REFERENCES}

1. Kunin C: U rinary Tract Infections. Detection, Prevention and $M$ anagement $5^{\text {th }}$ ed. Williams and Wilkins; 1997.

2. Svanborg C, Bergsten G, Fischer H, Frendeus B, Godaly G, Gustafsson E, Hang L, Hedlund $M$, Karpman $D$, Lundstedt $A C$, et al.: The 'innate' host response protects and damages the infected urinary tract. A nn M ed 2001, 33:563-570. 
3. Godaly G, Bergsten G, Hang L, Fischer H, Frendeus B, Lundstedt AC, Samuelsson $M$, Samuelsson $P$, Svanborg C: N eutrophil recruitment, chemokine receptors, and resistance to mucosal infection. J Leukoc Biol 2001, 69:899-906.

4. Roberts JA, Domingue GJ: Experimental pyelonephritis in the monkey. II. The prognostic value of radionuclide evaluation of the urinary tract. Invest $\mathrm{U}$ rol 1975, 12:374-380.

5. Hang L, Frendeus B, Godaly G, Svanborg C: Interleukin-8 receptor knockout mice have subepithelial neutrophil entrapment and renal scarring following acute pyelonephritis. J Infect D is 2000, 182:1738-1748.

6. Kunin CM, Deutscher R, Paquin A, Jr.: Urinary Tract Infection In School Children: An Epidemiologic, Clinical And Laboratory Study. M edicine (Baltimore) 1964, 43:91-130.

7. Lindberg U, Hanson LA, Jodal U, Lidin JG, Lincoln K, Olling S: Asymptomatic bacteriuria in schoolgirls. II. Differences in escherichia coli causing asymptomatic bacteriuria. A cta Paediatr Scand 1975, 64:432-436.

8. Bergsten G, Wullt B, Svanborg C: Escherichia coli, fimbriae, bacterial persistence and host response induction in the human urinary tract. Int J M ed M icrobiol 2005, 295:487-502.

9. Haraoka M, Hang L, Frendéus B, Godaly G, Burdick M, Strieter R, Svanborg C: Neutrophil recruitment and resistance to urinary tract infection. J Infect $D$ is 1999, 180:1220-1229.

10. Frendeus B, Godaly G, Hang L, Karpman D, Lundstedt AC, Svanborg C: Interleukin 8 receptor deficiency confers susceptibility to acute experimental pyelonephritis and may have a human counterpart. J Exp M ed 2000, 192:881890.

11. Kauffmann F: Über neue thermolabile Körperantigene der Colibakterien. Acta Path M icrobiol Scand 1943, 20:21-44.

12. Mabeck CE, Ørskov F, Ørskov I: Escherichia coli serotypes and renal involvement in urinary-tract infection. Lancet 1971, 1:1312-1314.

13. Svanborg-Edén C, Hanson LA, Jodal U, Lindberg U, Akerlund AS: Variable adherence to normal human urinary-tract epithelial cells of Escherichia coli strains associated with various forms of urinary-tract infection. Lancet 1976, 1:490-492.

14. de Man $P$, Jodal $U$, Lincoln $K$, Svanborg-Edén $C$ : Bacterial attachment and inflammation in the urinary tract. J Infect D is 1988, 158:29-35. 
15. Hedges $S$, Svensson $M$, Svanborg $C$ : Interleukin-6 response of epithelial cell lines to bacterial stimulation in vitro. Infect Immun 1992, 60:1295-1301.

16. Agace W, Hedges S, Andersson U, Andersson J, Ceska M, Svanborg C: Selective cytokine production by epithelial cells following exposure to Escherichia coli. Infect Immun 1993, 61:602-609.

17. Johnson J: Virulence factors in Escherichia coli urinary tract infection. Clin M icrobial Rev 1991, 4:80-128.

18. Donnenberg MS, Newman B, Utsalo SJ, Trifillis AL, Hebel RJ, Warren JW: Internalization of Escherichia coli into human kidney epithelial cells: Comparison of fecal and pyelonephritis-associated strains. J. Infec. Dis. 1994, 169:831-838.

19. Hacker J, Kaper JB: Pathogenicity islands and the evolution of microbes. Annu Rev M icrobiol 2000, 54:641-679.

20. Oelschlaeger TA, Dobrindt U, Hacker J: Virulence factors of uropathogens. Curr O pin U rol 2002, 12:33-38.

21. Schembri MA, Roos V, Ulett GC, Svanborg C, Klemm P: Molecular chracterisation of the Escherichia coli asymptomatic bacteruria strain 83972: The taming of a pathogen. Submitted. 2005.

22. Trifillis A, Donnenberg M, Cui X, Russell R, Utsalo S, Mobley H, Warren J: Binding to and killing of human renal epithelial cells by hemolytic Pfimbriated E.coli. Kid Int 1994, 46:1083-1091.

23. Malaviya R, Gao Z, Thankavel K, van der Merwe PA, A braham SN : The mast cell tumor necrosis factor alpha response to FimH-expressing Escherichia coli is mediated by the glycosylphosphatidylinositol-anchored molecule CD48. Proc N atl A cad Sci U S A 1999, 96:8110-8115.

24. Martinez JJ, Mulvey MA, Schilling JD, Pinkner JS, Hultgren SJ: Type 1 pilusmediated bacterial invasion of bladder epithelial cells. E mbo J 2000, 19:28032812.

25. Klumpp DJ, Weiser AC, Sengupta S, Forrestal SG, Batler RA, Schaeffer AJ: Uropathogenic Escherichia coli potentiates type 1 pilus-induced apoptosis by suppressing N F-kappaB. Infect Immun 2001, 69:6689-6695.

26. Schilling JD, Mulvey MA, Vincent CD, Lorenz RG, Hultgren SJ: Bacterial invasion augments epithelial cytokine responses to Escherichia coli through a lipopolysaccharide-dependent mechanism. J Immunol 2001, 166:1148-1155. 
27. Wullt B, Bergsten G, Connell H, Rollano P, Gebratsedik N, Hang L, Svanborg C: Pfimbriae trigger mucosal responses to Escherichia coli in the human urinary tract. Cell M icrobiol 2001, 3:255-264.

28. Samuelsson P, Hang L, Wullt B, Irjala H, Svanborg C: Toll-like receptor 4 expression and cytokine responses in the human urinary tract mucosa. Infect Immun 2004, 72:3179-3186.

29. Levin B, Svanborg-Edén C: Selection and evolution of virulence in bacteria: an ecumenical excursion and modest suggestion. Parasitology 1990, 100:S103S115.

30. Wold A, Caugant D, Lidin-Janson G, de Man P, Svanborg C: Resident colonic Escherichia coli strains frequently display uropathogenic characteristics. J Infect D is 1992, 165:46-52.

31. Jodal $U$, Lindberg $U$, Lincoln $\mathrm{K}$ : The natural history of bacteriuria in childhood. Infect D is Clin N orth A m 1987, 1:713-729.

32. Frendeus B, Godaly G, Hang L, Karpman D, Svanborg C: Interleukin-8 receptor deficiency confers susceptibility to acute pyelonephritis. J Infect D is 2001, 183 Suppl 1:S56-60.

33. Svanborg-Edén C, Hagberg L, Briles D, McGhee J, Michalek S: Susceptibility to Escherichia coli urinary tract infection and LPS responsiveness. In Genetic control of host resistance to infection and malignancy. Edited by Skamene E: Alan R. Liss; 1985:385-391.

34. Svanborg-Edén C, Hagberg L: U rinary white cell excretion related to LPS responsiveness. In Genetic control of host resistance to infection and malignancy. Edited by Skamene E: Alan R. Liss; 1985:393-398.

35. Shahin R, Engberg I, Hagberg L, Svanborg-Edén C: N eutrophil recruitment and bacterial clearance correlated with LPS responsiveness in local gramnegative infection. J Immunol 1987, 138:3475-3480.

36. Bergsten G, Samuelsson P, Wullt B, Leijonhufvud I, Fischer H, Svanborg C: PapG dependent adherence breaks mucosal inertia and triggers the innate immmune response. J Infect $D$ is 2004, 189:1734-1742.

37. Zhou L, Tan A, Hershenson MB: Yersinia YopJ inhibits pro-inflammatory molecule expression in human bronchial epithelial cells. Respir Physiol Neurobiol 2004, 140:89-97.

38. Ruckdeschel K, Mannel O, Richter K, Jacobi CA, Trulzsch K, Rouot B, Heesemann $J$ : Yersinia outer protein $\mathbf{P}$ of Yersinia enterocolitica simultaneously blocks 
the nuclear factor-kappa B pathway and exploits lipopolysaccharide signaling to trigger apoptosis in macrophages. J Immunol 2001, 166:1823-1831.

39. Johanson I-M, Plos K, Marklund B-I, Svanborg C: Pap, papG and prsG DNA sequences in Escherichia coli from the fecal flora and the urinary tract. M icrobial Path 1993, 15:121-129.

40. Plos K, Connell H, Jodal U, Marklund B, Mårild S, Wettergren B, Svanborg C: Intestinal carriage of $\mathbf{P}$ fimbriated Escherichia coli and the susceptibility to urinary tract infection in young children. I Infect D is 1995, 171:625-631.

41. Leffler $\mathrm{H}$, Svanborg-Edén $\mathrm{C}$ : Chemical identification of a glycosphingolipid receptor for Escherichia coli attaching to human urinary tract epithelial cells and agglutinating human erythrocytes. FEM S M icrobiol Lett 1980, 8:127-134.

42. Leffler H, Svanborg-Edén C: G lycolipid receptors for uropathogenic Escherichia coli on human erythrocytes and uroepithelial cells. Infect Immun 1981, 34:920929.

43. Breimer $M$ : Chemical and immunological identification of the Forssman pentaglycosylceramide in human kidneys. Glycoconjugate 1985, 2:375.

44. Hedlund M, Svensson M, Nilsson $\AA$, Duan R, Svanborg C: Role of the ceramide signalling pathway in cytokine responses to $P$ fimbriated Escherichia coli. J Exp M ed 1996, 183:1-8.

45. Hedlund M, Frendeus B, Wachtler C, Hang L, Fischer H, Svanborg C: Type 1 fimbriae deliver an LPS- and TLR4-dependent activation signal to CD 14negative cells. M ol M icrobiol 2001, 39:542-552.

46. Svensson M, Frendeus B, Butters T, Platt F, Dwek R, Svanborg C: Glycolipid depletion in antimicrobial therapy. M ol M icrobiol 2003, 47:453-461.

47. Frendeus $B$, Wachtler $C$, Hedlund $M$, Fischer $H$, Samuelsson $P$, Svensson $M$, Svanborg C: Escherichia coli $P$ fimbriae utilize the Toll-like receptor 4 pathway for cell activation. M ol M icrobiol 2001, 40:37-51.

48. Fischer H, Yamamoto M, H oebe K, Ragnarsdottir B, A kira S, Beutler B, Svanborg $C$ : Pathogens and commensals use different TLR4 signal transduction pathways in the mucosa. Submitted 2005.

49. Wright SD, Ramos RA, Tobias PS, Ulevitch RJ, Mathison JC: CD 14, a receptor for complexes of lipopolysaccharide (LPS) and LPS binding protein. Science 1990, 249:1431-1433. 
50. Adachi O, Kawai T, Takeda K, Matsumoto M, Tsutsui H, Sakagami M, Nakanishi $\mathrm{K}$, A kira S: Targeted disruption of the MyD 88 gene results in loss of IL-1and IL-18-mediated function. Immunity 1998, 9:143-150.

51. Yamamoto M, Sato S, Hemmi H, Sanjo H, Uematsu S, Kaisho T, Hoshino K, Takeuchi O, Kobayashi M, Fujita T, et al.: Essential role for TIRAP in activation of the signalling cascade shared by TLR2 and TLR4. $\mathrm{N}$ ature 2002, 420:324-329.

52. Kawai T, A dachi O, Ogawa T, Takeda K, Akira S: Unresponsiveness of M yD 88deficient mice to endotoxin. Immunity 1999, 11:115-122.

53. Suzuki N, Suzuki S, Yeh WC: IRAK-4 as the central TIR signaling mediator in innate immunity. Trends Immunol 2002, 23:503-506.

54. Backhed F, Meijer L, Normark S, Richter-Dahlfors A: TLR4-dependent recognition of lipopolysaccharide by epithelial cells requires SCD 14. Cell M icrobiol 2002, 4:493-501.

55. Fischer H, Samuelsson P, Svensson M, Ekström K, Gustafsson L, Svanborg C: Ceramide as a putative signalling intermediate between PapG receptors and TLR4. Submitted 2005.

56. Godaly G, Proudfoot AEI, Offord RE, Svanborg C, Agace W: Role of epithelial interleukin-8 and neutrophil IL-8 receptor $A$ in Escherichia coli -induced transuroepithelial neutrophil migration. Infect I mmun 1997, 65(8):3451-3456.

57. Agace W, Hedges S, Ceska M, Svanborg C: IL-8 and the neutrophil response to mucosal G ram negative infection. J Clin Invest 1993, 92:780-785.

58. Hang L, Haraoka M, Agace WW, Leffler H, Burdick M, Strieter R, Svanborg C: Macrophage inflammatory protein-2 is required for neutrophil passage across the epithelial barrier of the infected urinary tract. J Immunol 1999, 162:3037-3044.

59. Otto G, Burdick M, Strieter R, Godaly G: Chemokine response to febrile urinary tract infection. Kidney Int 2005, 68:62-70.

60. Godaly G, Otto G, Burdick M, Strieter RM, Svanborg C: Fimbrial lectins determine the chemokine repertoire of infected uro-epithelial cells. Submitted 2005.

61. Baggiolini M, Dewald B, Moser B: Human chemokines: an update. Annu Rev Immunol 1997, 15:675-705.

62. Damaj BB, McColl SR, Mahana W, Crouch MF, N accache PH: Physical association of G i2al pha with interleukin-8 receptors. J Biol Chem 1996, 271:12783-12789. 
63. Laudanna C, Mochly-Rosen D, Liron T, Constantin G, Butcher EC: Evidence of zeta protein kinase $C$ involvement in polymorphonuclear neutrophil integrin-dependent adhesion and chemotaxis. J Biol Chem 1998, 273:3030630315.

64. Godaly G, Hang L, Frendeus B, Svanborg C: Transepithelial neutrophil migration is CXCR 1 dependent in vitro and is defective in IL-8 receptor knockout mice. J Immunol 2000, 165:5287-5294.

65. Svanborg S, Godaly G: Bacterial virulence in urinary tract infection. Infectious disease clinincs of north america 1997, 11:513-529.

66. Lomberg $\mathrm{H}$, Jodal U, Svanborg-Edén $\mathrm{C}$, Leffler $\mathrm{H}$, Samuelsson B: P1 blood group and urinary tract infection. Lancet 1981, i:551-552.

67. Lindstedt R, Larson G, Falk P, Jodal U, Leffler H, Svanborg-Edén C: The receptor repertoire defines the host range for attaching Escheridhia coli recognizing globo-A. Infect Immun 1991, 59:1086-1092.

68. Svensson M, Lindstedt R, Radin N, Svanborg C: Epithelial glycosphingolipid expression as a determinant of bacterial adherence and cytokine production. Infect Immun 1994, 62:4404-4410.

69. Medzhitov R, Preston-Hurlburt P, Janeway CA, Jr.: A human homologue of the Drosophila Toll protein signals activation of adaptive immunity. $N$ ature 1997, 388:394-397.

70. Smirnova I, Poltorak A, Chan EK, McBride C, Beutler B: Phylogenetic variation and polymorphism at the toll-like receptor 4 locus (TLR4). Genome Biol 2000, 1:RESEARCH 002.

71. Poltorak A, He X, Smirnova I, Liu MY, Van Huffel C, Du X, Birdwell D, Alejos E, Silva $M$, Galanos $C$, et al.: Defective LPS signaling in $\mathrm{C} 3 \mathrm{H} / \mathrm{HeJ}$ and C57BL/10ScCr mice: mutations in TIr4 gene. Science 1998, 282:2085-2088.

72. Ragnarsdottir B, Samuelsson M, Karpman D, Svanborg C: TLR4 genotype and protein expression in children with asymptomatic becteriuria. Submitted 2005.

73. Lundstedt AC, McCarthy S, Godaly G, Karpman D, Leijonhufvud I, Samuelsson $M$, Svensson $M$, Andersson $B$, Svanborg $C$ : Chemokine receptor polymorphisms in patients susceptible to acute pyelonephritis. Submitted 2005. 


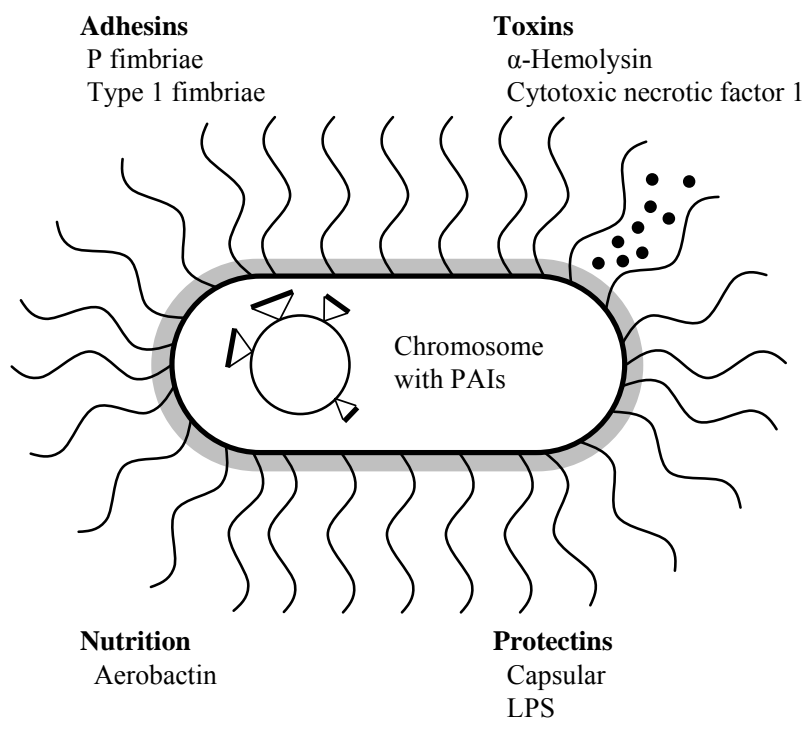

B

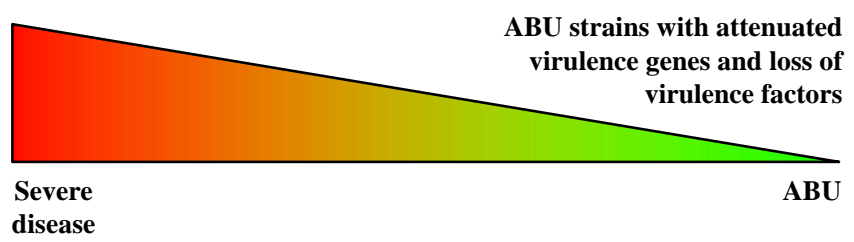

Figure 1. Differences between virulent uropathogenic $E$. coli (UPEC) strains and asymptomatic bacteriuria (ABU) strains

A. Fully virulent UPEC possess a wide arsenal of virulence factors that include adherence factors (fimbriae) and toxins (LPS, hemolysin) and cause severe infections such as pyelonephritis and bacteraemia.

B. Attenuated $A B U$ strains acquire mutations in fimbrial genes, pathogenicity islands (PAIs). 


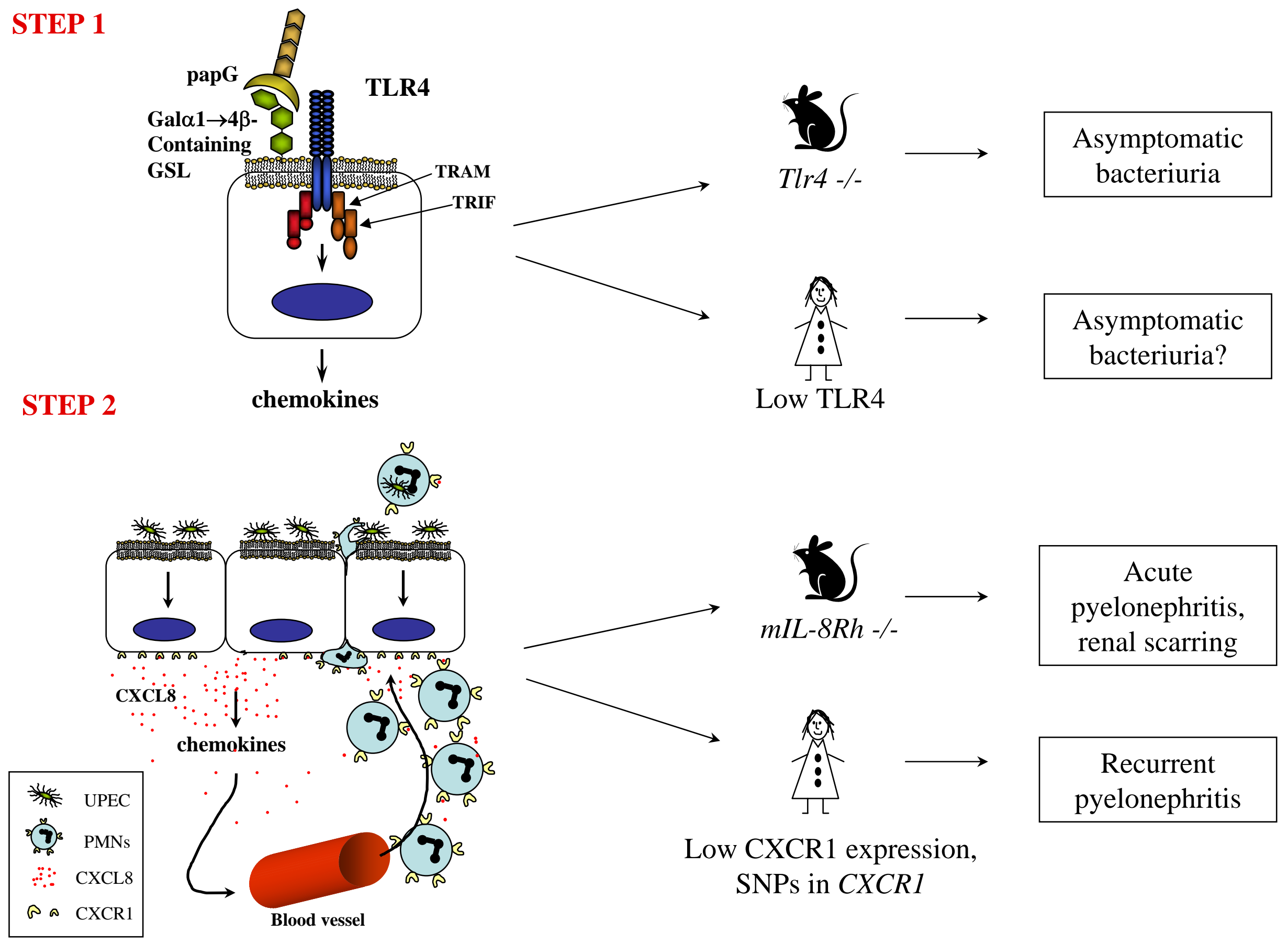


Figure 2 Host response induction by adhering bacteria

Step 1: P-fimbriated E. coli adhere to the Gal $\alpha 1-4 G a l \beta$ receptor epitope in the globoseries of glycosphingolipids (GSLs) on the uroepithelium and activate epithelial cells through TLR4 and the adaptor proteins, TRIF/TRAM. If TIr4 signalling is abrogated, mice develop an asymptomatic carrier state. These findings predict that ABU patients may have modified TLR4 function.

Step 2: Activated epithelial cells respond by secretion of CXCL8 and by expression of CXCR1. Neutrophils are recruited to the mucosa and eliminate the bacteria after migrating across the epithelial barrier. If CXCR1 (mIL-8Rh) is absent, mice develop acute septic pyelonephritis and renal scarring. Patients prone to pyelonephritis have reduced level of CXCR1 and new polymorphisms in the CXCR1 gene. 